\title{
Pengaruh Fraksi Hampa Pada Pipa Sempit Dengan Permukaan Dalam Berbentuk Spiral Terhadap Perpindahan Kalor Dua Fasa Pola Aliran Gelembung
}

\author{
Wardoyo $^{1}$, Supria Wiganda ${ }^{2}$, Arif Wahrudin ${ }^{3}$ \\ Educational Mechanical Engineering, State University of Jakarta $(\text { UNJ })^{1}$ \\ wardoyo_mt@yahoo.co.id \\ Educational Mechanical Engineering, State University of Jakarta $(U N J)^{2}$ \\ Studen of Educational Mechanical Engineering, State University of Jakarta (UNJ) ${ }^{3}$
}

\begin{abstract}
ABSTRAK
Berdasarkan data Badan Pusat Statistik, jumlah penduduk Indonesia meningkat sangat pesat dari tahun 2000 hingga 2010 sebesar 31.376.731 jiwa. Peningkatan jumlah penduduk berbanding lurus dengan konsumsi listrik. Untuk memenuhi kebutuhan pasokan listrik pemerintah membangun berbagai pembangkit listrik, salah satunya pembangkit listrik tenaga uap (PLTU). Upaya peningkatan potensi effisiensi PLTU dilakukan dengan meningkatkan koefisien perpindahan kalor dua fasa. Penelitian ini bertujuan untuk mengetahui pengaruh debit air, debit udara dan kemiringan pipa terhadap koefisien perpindahan kalor dua fasa pola aliran gelembung. Penelitian ini dilakukan dengan mengalirkan udara dengan debit $20 \mathrm{~cm} 3 / \mathrm{menit}$, $40 \mathrm{~cm} 3 /$ menit dan $60 \mathrm{~cm} 3 /$ menit. Mengalirkan air dengan debit 2 LPM, 4 LPM dan 6 LPM. Peneliti menggunakan pipa tembaga panjang $2.200 \mathrm{~mm}$ dengan diameter dalam $14 \mathrm{~mm}$ dan diameter luar $16 \mathrm{~mm}$. Pipa tersebut dipanaskan dengan nikelin berdiameter 0,8 mm yang dibuat melingkari pipa sepanjang 2.000 mm. Pada pipa tersebut dipasang 4 buah termokopel untuk membaca suhu yaitu input air, output air, input dinding pipa tembaga, dan output dinding pipa tembaga. Hasil penelitian menunjukan bahwa terdapat pengaruh positif fraksi hampa pada pipa sempit dengan permukaan dalam berbentuk spiral terhadap terhadap koefisien perpindahan kalor. Pertambahan nilai fraksi hampa menghasilkan gelembung yang jumlahnya lebih banyak, keberadaan permukaan dalam berbentuk spiral mengakibatkan gerakan gelembung semakin acak dan lebih merata pada permukaan melintang pipa. Dua faktor ini menghasilkan peningkatan koefisien perpindahan kalor.
\end{abstract}

Kata kunci: Koefisien Perpindahan Kalor, Dua Fasa, Aliran Gelembung

\section{Pendahuluan}

Aliran dua -fasa merupakan bagian dari aliran multi-fasa, studi tentang aliran dua fasa dapat dibedakan menjadi beberapa bagian, yaitu : wujud fasa (udara-cair, cairpadat, dan padat-padat), arah aliran (searah ke atas, searah ke bawah, dan berlawanan arah), dan kedudukan saluran (mendatar, tegak atau miring).

Berbagai fenomena perpindahan kalor aliran dua fasa banyak dijumpai di sekitar kehidupan kita sehari-hari maupun di dalam industri, seperti pada ketel uap, kondensor, alat penukar kalor (heat exchangers), reaktor nuklir, pencairan gas alam. Untuk aliran dua fasa dua komponen dapat kita jumpai pada industri pengeboran minyak, dalam proses pengeboran diperoleh gas alam dan minyak mentah yang mengalir secara bersamaan di dalam pipa. Perpindahan kalor yang terjadi ditentukan oleh koefisien perpindahan kalor yang dalam hal ini dipengaruhi oleh hubungan yang sangat komplek antara properti fluida, dimensi, kedudukan pipa dan kondisi permukaan pipa serta pola aliran dua fasa yang terjadi.

Inovasi-inovasi yang dilakukan terhadap perpindahan kalor dari alat penukar kalor bertujuan untuk mengatasi beberapa permasalahan seperti laju perpindahan kalor, faktor gesekan, karakteristik aliran fluida, luas permukaan perpindahan kalor, daya pompa, serta jenis material yang digunakan untuk memindahkan kalor pada penukar kalor.

Clemen C. tang dan Afshin J Ghajar (2007) meneliti perpindahan kalor dua fasa air-udara dengan berbagai pola aliran pada pipa miring mulai dari posisi Horisontal, $2^{0}$, $5^{0}, \quad 7^{0}$ menggunakan pipa stainless steel berdiameter $27,9 \mathrm{~mm}$, perbandingan panjang 
dan diameter 95 dengan jumlah total data yang dihasilkan 763 data. Selanjutnya korelasi yang dihasilkan divalidasi dengan 6 korelasi yang dihasilkan beberapa peneliti sebelumnya dan disimpulkan bahwa korelasi yang dihasilkan akurasinya masuk akal $( \pm 30 \%)$ serta dapat diaplikasikan untuk beberapa pola aliran dan sudut kemiringan pipa $\left(0^{0}, 2^{0}, 5^{0}, 7^{0}\right)$

Ishak, et al meneliti tentang pengaruh ketebalan inner-helical fin terhadap peforma dan karakteristik pada head exchanger dengan ketebalan inner-helical fin $1 \mathrm{~mm}$, $2 \mathrm{~mm}$ dan $3 \mathrm{~mm}$. Secara keseluruhan laju perpindahan kalor dan bilangan Nusselt mengalami peningkatan berturut-turut sebesar $148,023 \%, 152,164 \%$ dan $156,759 \%$ dari plain tube pada laju aliran volumetrik air panas yang sama 900lpm. Pada debit yang sama (900lpm) faktor gesekan juga mengalami peningkatan. Untuk inner-helical fin dengan ketebalan $\mathrm{t}=3 \mathrm{~mm}$ faktor gesekan mengalami peningkatan rata-rata $63 \%$ dari plain tube tepatnya pada $\mathrm{f}=0,093$.

Berbagai upaya sudah dilakukan untuk memprediksi dinamika fluida dan koefisien perpindahan kalor pada aliran dua fasa dengan beberapa bentuk pola aliran telah banyak dilakukan secara analitis maupun eksperimental, namun pada aliran dua fasa dengan kedudukan pipa horisontal yang berkontur ulir di dalam belum begitu banyak literatur yang membahas. Fenomena dinamika fluida dan perpindahan kalor aliran dua fasa pada pipa berkontur ulir dalamnya dengan variasi kemiringan pipa $0^{\circ} 10^{\circ} 20^{\circ} 30^{\circ}$ $40^{\circ} 50^{\circ}$ dari posisi horisontal menarik untuk diteliti.

\section{Metode}

Metode yang digunakan dalam penelitian ini adalah eksperimen, dilakukan di Laboratorium Otomotif, Jurusan Otomotif Universitas Negeri Jakarta. Peneliti merancang desain sebuah alat untuk membantu jalannya penelitian ini, skemanya seperti yang terlihat pada gambar-1. Sebagai seksi uji dipilih pipa tembaga berdiameter $14 \mathrm{~mm}$ dengan panjang keseluruhan $2200 \mathrm{~mm}$, panjang yang seksi uji yang dipanaskan $2000 \mathrm{~m}$.

Pemanas yang digunakan terbuat dari kawat nikelin berdiameter $0,9 \mathrm{~mm}$ yang dibungkus cincin keramik berdiameter $5 \mathrm{~mm}$, selanjutnya dibungkus dengan sabuk asbes setebal $15 \mathrm{~mm}$, lapisan berikutnya glaswoll setebal $25 \mathrm{~mm}$, dan lapisan selanjutnya aluminium foil sebanyak tiga lapis. Untuk menjaga teperatur seksi uji pada nilai tertentu digunakan thermostat yang akan memutus aliran listrik ke pemanas jika temperatur yang diinginkan telah tercapai.

Air yang digunakan adalah air tanah dari sumur yang berada disekitar Laboratorium Otomotif, setelah melewati seksi uji terparatur air akan naik sehingga tidak disirkulasikan lagi. Udara yang digunakan bersumber dari kompressor yang terletak di Laboratorium Otomotif.

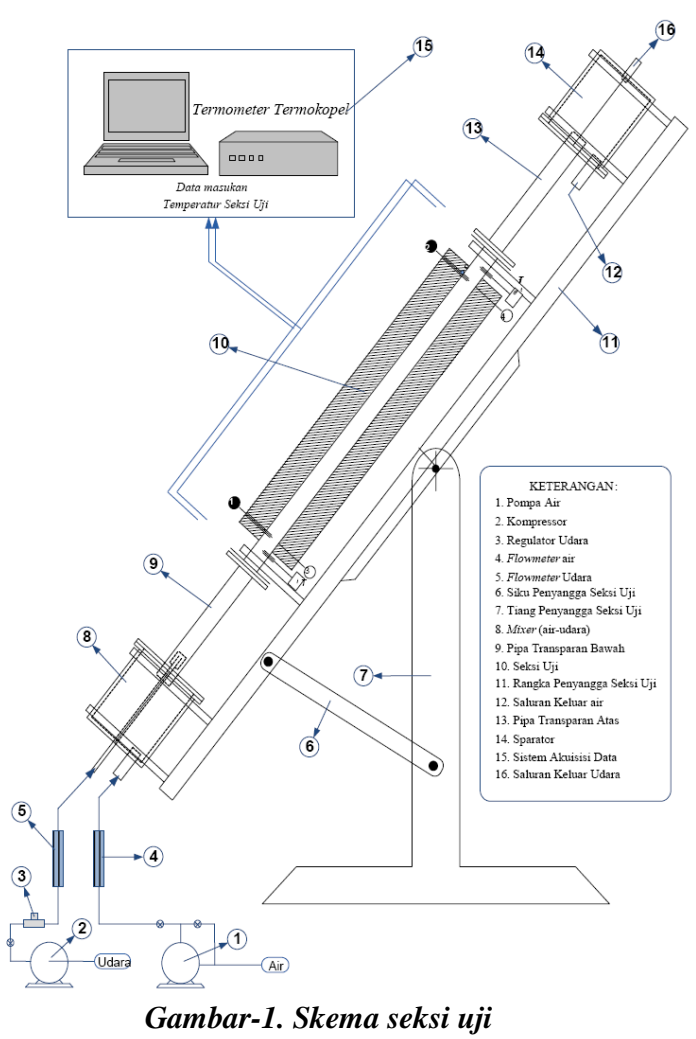

\subsection{Metode Pengumpulan Data}

Gelembung udara pada percobaan ini sepenuhnya dihasilkan oleh pembangkit gelembung airator aquarium yang dipasang pada mixer, diharapkan gelembung yang terbentuk dapat menyebar merata dalam aliran. Untuk mengamati bentuk dan distribusi gelembung dalam aliran, pada alat percobaan dipasang pipa transparan pada inlet dan outlet seksi uji.

Pada pipa tembaga yang digunakan sebagai seksi uji panjangnya $2200 \mathrm{~mm}$ dan berdiameter $14 \mathrm{~mm}$ dipasang lima 
termokopel untuk mengukur temperatur dinding pipa dan lima termokopel untuk mengukur temperatur fluida pada lima titik. Pemanas listrik yang digunakan berkekuatan maksimum 2,2 kW. Temperatur aliran diukur dengan dua termokopel dipasang ditengahtengah aliran pada inlet dan outlet seksi uji. Pipa tembaga dipanaskan hanya sampai temperatur jenuh fluida, agar tidak terjadi nucleate boilling yang akan mengganggu aliran gelembung yang sedang diteliti.

Debit aliran tiap fasa diatur dengan kran dan regulator serta diukur dengan flowmeter. Keseluruhan peralatan percobaan seperti terlihat pada gambar - 1 .

\subsection{Metode Analisis Data}

Secara eksperimental, koefisien perpindahan kalor dua fasa dapat ditentukan dari hukum Newton tentang pendinginan, yaitu:

$$
\begin{aligned}
& \text { htp }=\frac{q^{\prime \prime}}{T_{w}-T_{f}} \\
& \text { dengan : } \\
& \text { q" = fluks kalor }(\mathrm{W} / \mathrm{m} 2) \\
& \mathrm{Tw}=\text { suhu dinding saluran } \\
& \text { Tf = suhu fluida }
\end{aligned}
$$

Fluks kalor didefinisikan sebagai besarnya kalor yang diserap oleh fluida pada saat mengalir di sepanjang seksi uji persatuan luas penampang yang dilaluinya, sehingga besarnya fluks kalor dapat diperoleh dari persamaan sebagai berikut :

$$
q^{\prime \prime}=\frac{Q}{A}
$$

$$
\text { dengan : }
$$

$\mathrm{Q}=$ Kalor yang dapat diserap oleh fluida

$\mathrm{A}=$ Luas permukaan dalam pipa uji

Besarnya kalor yang dapat diserap oleh fluida diperoleh dari persamaan berikut :

$$
Q=\dot{m} c p_{t p} \cdot\left(T_{\text {out }}-T_{i n}\right) \text {. }
$$

dengan :

$\dot{m}=$ Laju aliran massa total

$T_{i n}=$ Temperatur fluida masuk seksi uji

$T_{\text {out }}=$ Temperatur fluida keluar seksi uji

$c p_{t p}=$ Kalor jenis dua fasa

$c p_{t p}=\omega_{a} c p_{a}+\omega_{l} c p_{l}$

dengan

$\omega_{\mathrm{a}} \quad=$ fraksi massa udara

$$
\begin{aligned}
& \omega_{a}=\frac{\rho_{a}}{\rho_{a}+\rho_{l}} \\
& \omega_{1}=\text { fraksi massa air } \\
& \omega_{l}=\frac{\rho_{l}}{\rho_{a}+\rho_{l}}
\end{aligned}
$$

\section{Hasil dan Pembahasan}

\subsection{Bentuk pola aliran}

Variasi bentuk pola aliran berubah seiring dengan pertambahan fraksi hampa. Hal ini dimungkinkan karena semakin besar fraksi hampa, semakin besar pula volume udara yang masuk seksi uji.

Pada sisi masuk seksi uji bentuk gelembung cenderung bulat membesar, setelah melewati seksi uji dan gelembung terbentur spiral yang terpasang di dalamnya sehingga gelebung pecah menjadi butiran yang lebih kecil. Akibat lain dari benturan gelembung dengan spiral yang ada dalam seksi uji menyebabkan butiran gelembung lebih menyebar ketengah pipa.
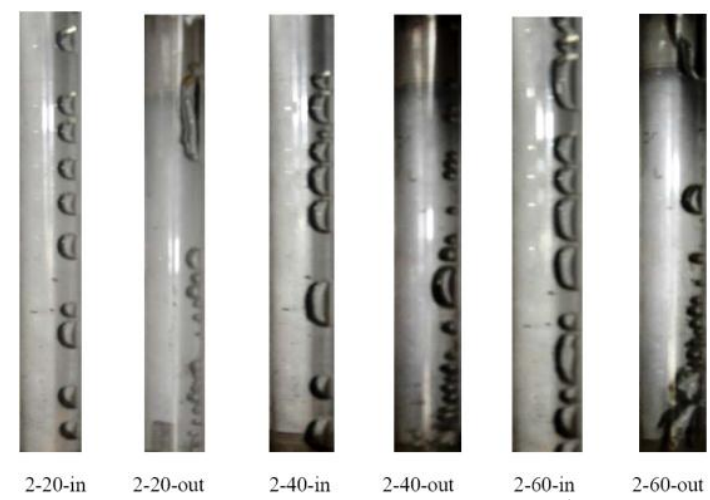

Gambar-2. Sudut kemiringan pipa $0^{0}$
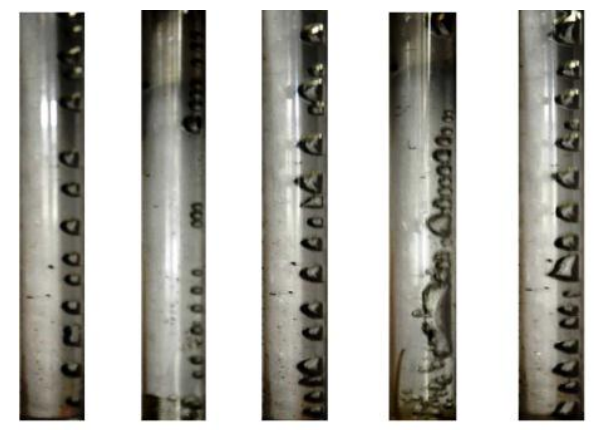

$2-20-1$
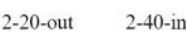

2-40-out

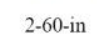

Gambar-3. Sudut kemiringan pipa $10^{0}$ 


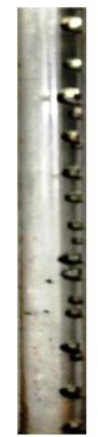

2-20-in

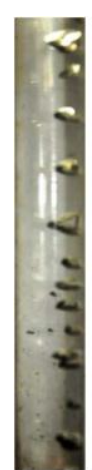

2-20-in

2-20-out
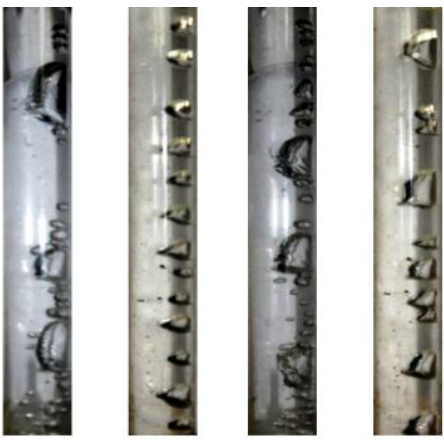

2-20-out

2-40-in

2-40-out 2-60-in

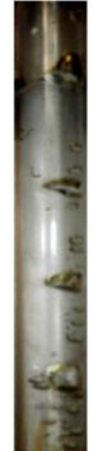

Gambar-5. Sudut kemiringan pipa $30^{\circ}$
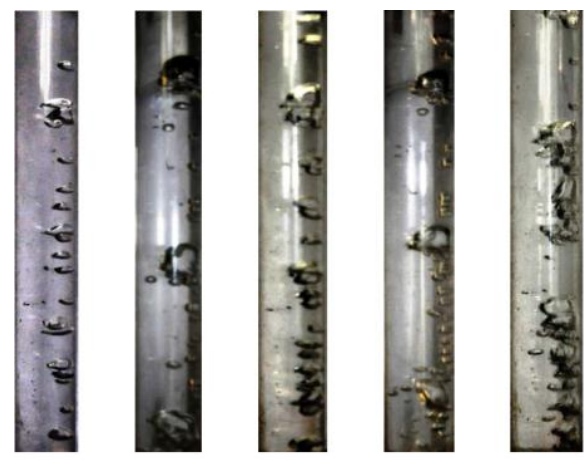

2-20-in

2-20-out 2-40-in 2-40-out 2-60-in Gambar-6. Sudut kemiringan pipa 40

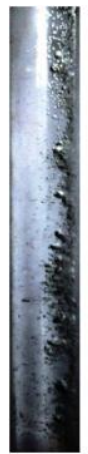

2-20-in

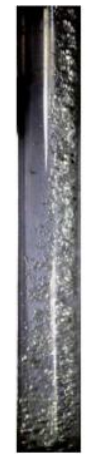

2-20-ou

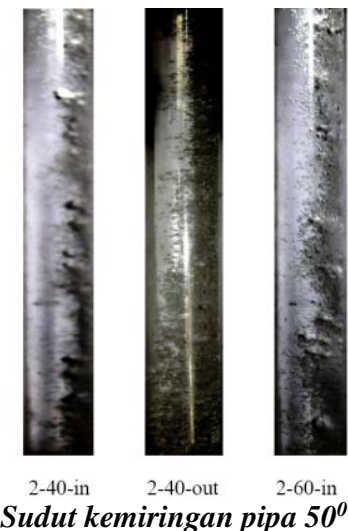

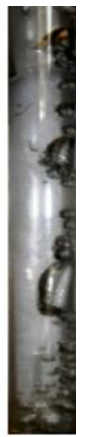

2-60-out

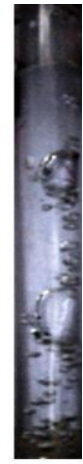

2-60-ou

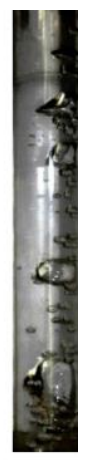

2-60-out

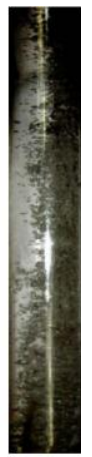

2-60-out
Pada saat posisi pipa horizontal, gelembung udara mengalami gaya pengapungan ke atas, tegak lurus terhadap arah aliran air dalam pipa, sehingga gelembung mengalir di sisi dalam bagian atas sepanjang pipa. Gerakan gelembung bergesekan dengan diding pipa dan tidak lancar. Gelembung yang awalnya keluar dari aerator aquarium berbentu butiran halus kemudian terjadi penggabungan sehingga berukuran lebih besar. Dengan ada penghalang berupa spiral di dalam pipa, maka gelembung pecah dan sedikit bergeser ke tengah. Sesaat setelah gelembung melewati spiral terjadi penggabungan kembali dan berukuran lebih besar.

Pada penelitian ini sudut kemiringan pipa di variasi mulai posisi horizontal $\left(0^{0}\right)$, $10^{\circ}, 20^{\circ}, 30^{\circ}, 40^{\circ}, 50^{\circ}$. Semakin bertambah sudut kemiringan pipa maka gaya pengapungan akan semakin sejajar dengan arah aliran air dalam pipa, hal ini menyebabkan pergerakan gelembung akan semakin lancar, butiran yang terbentuk berukuran semakin kecil dan gerakkannya akan semakin ke tengah di sepanjang pipa.

\subsection{Koefisien perpindahan kalor dua fasa}

Setelah dilakukan perhitungan secara seksama diperoleh hasil sebagai berikut:

Tabel 1: Perpindahan kalor dua fasa pada pipa miring

\begin{tabular}{||c|c|c|c||}
\hline $\begin{array}{c}\text { Debit udara } \\
\text { (cc/min) }\end{array}$ & $\begin{array}{c}\text { Kemiringan } \\
\text { pipa }\end{array}$ & $\begin{array}{c}\text { Fluks } \\
\text { kalor }(\mathrm{q} ")\end{array}$ & $\begin{array}{c}\mathrm{H}_{\mathrm{tp}} \\
\left(\mathrm{Watt} / \mathrm{m}^{2}{ }^{\circ} \mathrm{C}\right)\end{array}$ \\
\hline \hline \multirow{5}{*}{20} & $0^{0}$ & $1,059.76$ & 522.62 \\
\cline { 2 - 4 } & $10^{0}$ & $2,861.36$ & $1,411.08$ \\
\cline { 2 - 4 } & $20^{0}$ & $2,914.35$ & $1,437.21$ \\
\cline { 2 - 4 } & $30^{0}$ & $3,073.32$ & $1,515.61$ \\
\cline { 2 - 4 } & $40^{0}$ & $2,914.35$ & $1,437.21$ \\
\cline { 2 - 4 } & $50^{0}$ & $3,020.33$ & $1,489.48$ \\
\hline \multirow{5}{*}{40} & $0^{0}$ & $1,430.85$ & 705.63 \\
\cline { 2 - 4 } & $10^{0}$ & $2,914.70$ & $1,437.39$ \\
\cline { 2 - 4 } & $20^{0}$ & $3,020.69$ & $1,489.65$ \\
\cline { 2 - 4 } & $30^{0}$ & $2,967.70$ & $1,463.52$ \\
\cline { 2 - 4 } & $40^{0}$ & $2,861.71$ & $1,411.25$ \\
\hline \multirow{4}{*}{60} & $50^{0}$ & $2,861.71$ & $1,411.25$ \\
\hline & $0^{0}$ & $2,279.04$ & $1,123.91$ \\
\cline { 2 - 4 } & $10^{0}$ & $3,074.06$ & $1,515.97$ \\
\cline { 2 - 4 } & $20^{0}$ & $3,339.06$ & $1,646.57$ \\
\hline & $30^{0}$ & $2,756.05$ & $1,359.15$ \\
\cline { 2 - 4 } & $40^{0}$ & $3,180.06$ & $1,568.25$ \\
\cline { 2 - 4 } & $50^{0}$ & $3,233.06$ & $1,594.38$ \\
\hline
\end{tabular}

Untuk memudahkan menganalisa kecenderungan perubahan koefisien perpindahan kalor dua fasa, selanjutnya hasil 
penelitian ini disajikan dalam bentu grafik sebagai berikut:

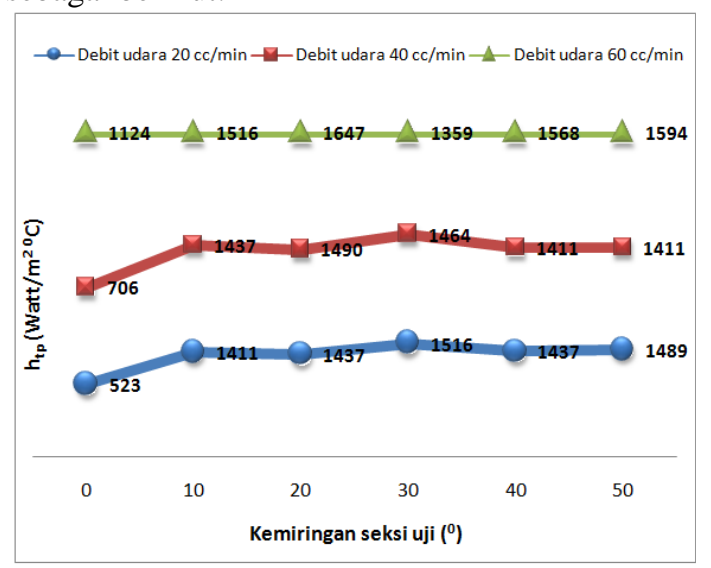

Gambar-8. Skema seksi uji Debit air 2 lpm

Berdasarkan grafik di atas, pengaruh kemiringan seksi uji menghasilkan koefisien perpindahn kalor yang bervariasi. seperti yang terlihat pada debit air 6 liter/menit menghasilkan koefisien perpindahan kalor tertinggi dibandingkan debit air lainnya. Dan pada debit air 4liter/menit koefisien perpindahan kalor tertinggi ada pada sudut $20^{\circ}$ pada sudut $30^{\circ}$ dan seterusnya mengalami penurunan koefisien perpindahan kalor.

\section{Kesimpulan}

Dari hasil penelitan eksperimen, analisa perhitungan dan pembahasan yang telah diuraikan sebelumnya, maka dapat ditarik kesimpulan sebagai berikut :

Terdapat pengaruh kemiringan pipa berulir-dalam terhadap koefisien perpindahan kalor.

Penambahan debit udara menghasilkan gelembung yang jumlahnya lebih banyak dengan ukuran yang lebih besar.

Penambahan debit air menghasilkan gelembung yang lebih sedikit jumlahnya dengan ukuran yang mengecil.

Kemiringan pipa menghasilkan gelembung dengan posisi dan bentuk yang bervariasi karena semakin besar sudutkemiringan pipa, semakin kecil gaya gravitasi yang mempengaruhi gelembung sehingga bentuk gelembungnya menjadi lebih pipih.

Penambahan debit udara pada debit air yang tetap menghasilkan peningkatan koefisien perpindahan kalor.

Semakin acak posisi gelembung, perpindahan kalor yang terjadi akan semakin baik. Hal ini karena perpindahan kalor dari dinding pipa ke gelembung lalu menuju ke air akan semakin cepat.

Semakin pipih bentuk gelembung yang terbentuk, perpindahan kalor yang terjadi semakin baik. Hal ini karena luas penampang gelembung yang semakin besar sehingga proses perpindahan kalor menjadi lebih cepat.

Debit air 6liter/menit pada sudut $0^{0}$ menghasilkan koefisien perpindahan kalor yang terbesar dibandingkan debit air yang lain.

\section{Daftar Pustaka}

[1] Artono, Raldi K., Sasanti Proborini. Aliran Dua Fase dan Fluks Kalor Kritis. Jakarta : Salemba Teknik, 1994.

[2] Ghajar, Afsin J., Clement C. Tang. "Advances in Void Fraction Flow Pattern Maps and Non-Boiling Heat Transfer Two-Phases Flow in Pipes with Various Inclination,"Advance in Multiphase Flow and Heat Transfer, Vol.1 (2009), hal. 1-52.

[3] Ghajar, Afsin J., Clement C. Tang. "Validation of a General Heat Transfer Correlation For Non-Boiling Two Phase Flow with Different Flow Patterns and Pipe Inclination Angles," ASME-JSME Thermal Engineering Summer Heat Transfer Conference, Vol.2 (Januari, 2007), hal. 205-218.

[4] Ghajar, Afsin J., Clement C. Tang. "Void Fraction and Flow Patterns of Two-Phase in Upward and Downward Vertical and Horizontal Pipes,"Advance in Multiphase Flow and Heat Transfer, Vol.4 (2012), hal. 175-201.

[5] Incopera, Frank P. Introduction to Heat Transfer. Indiana: John Wiley \& Sons, 2011.

[6] Kreith, Frank. Prinsip-prinsip Perpindahan Panas, terj Arko Prijono. Jakarta: Penerbit Erlangga, 1997.

[7] Lunde, Peter J. Solar Thermal Engineering : Space Heating and Hot Water Systems. New York: John Wiley \& Sons, 1980.

[8] Mahasiswa Pascasarjana Departemen Teknik Mesin FTUI. Perpindahan Kalor Pendidihan dan Aliran Dua Fase. Depok: Departemen Teknik MesinFakultasTeknik Universitas Indonesia. 2012. 
[9] Usman, Ishak. "Pengaruh Ketebalan Inner-Helical Fin Terhadap Characteristic of Performance Pada Head Exchanger," Jurnal Rekayasa Mesin, Vol.1 (2010), hal 108-114. 